JURNAL ILMU PENDIDIKAN INDONESIA ISSN: 2338-3402

Volume: 5 Nomor: 2

1 Juni 2017

\title{
PENGARUH PENGGUNAAN METODE EKSPERIMEN TERHADAP MINAT, KEAKTIFAN DAN HASIL BELAJAR PADA MATERI GELOMBANG BUNYI SISWA KELAS XII IPA 1 SMA NEGERI 1 RAJA AMPAT KABUPATEN RAJA AMPAT
}

\author{
Eka Iriyanti $^{1)}$ dan Virman ${ }^{2)}$ \\ ${ }^{1)}$ Guru SMA NEGERI 1 Raja Ampat Kabupaten Raja Ampat \\ ${ }^{2)}$ Dosen Program Studi Magister Pendidikan IPA Universitas Cenderawasih
}

Abstract. The purpose of this research is to know: (1) influence of experimental method to study interest, (2) influence of experiment method to learning activity, (3) influence of experiment method to learning result, (4) improvement of learning result on wave material the sound of class XII students IPAI SMA Negeri 1 Raja Ampat Raja Ampat District. This type of research is a correlational quantitative research. The sample in this study is the students of class XII IPA1 SMA Negeri 1 Raja Ampat Raja Ampat Regency which amounted to 35 students. The result of the research shows that (1) there is a strong influence between experimental method of using learning method equal to $r=0,709$ with contribution 50,3\%, while the influence of experiment method to learning interest is $(t c t=5,774)>($ ttable $=1,697)$ or significance value $0.00<0.05$, (2) there is a strong influence between experimental method of using learning method $r$ $=0,854$ with donation equal to $73 \%$, while the influence of experiment method to learning activity is (tct $=9,437)>($ ttabel $=1,697)$ or significance value $0.00<0.05$, (3) there is a strong influence between the variables of the use of experimental methods on learning outcomes of $r=0,531$ with a contribution of $28.2 \%$, while the amount of influence of use experimental method of learning result is $(t c t=9,437)>$ (ttable $=1,697)$ or significance value 0,00<0,05, (4) there is improvement of result lecture on the matter of sound waves of students of class XII IPA1 SMA Negeri 1 Raja Ampat Raja Ampat District of 0.58 which is included in the medium category.

Keywords: Experimental Method, Interest Learning, Activity Learning, Learning Results, Sound Waves

Abstrak Tujuan penelitian ini adalah untuk mengetahui: (1) pengaruh penggunaan metode eksperimen terhadap minat belajar, (2) pengaruh penggunaan metode eksperimen terhadap keaktifan belajar, (3) pengaruh penggunaan metode eksperimen terhadap hasil belajar, (4) peningkatan hasil belajar pada materi gelombang bunyi siswa kelas XII IPA ${ }_{1}$ SMA Negeri 1 Raja Ampat Kabupaten Raja Ampat. Jenis penelitian ini adalah penelitian kuantitatif berbentuk korelasional. Sampel dalam penelitian ini adalah siswa kelas XII IPA 1 SMA Negeri 1 Raja Ampat Kabupaten Raja Ampat yang berjumlah 35 siswa. Hasil penelitian menunjukkan (1) terdapat pengaruh yang kuat antara variabel penggunaan metode eksperimen terhadap minat belajar sebesar $r=0,709$ dengan besar sumbangan 50,3\%, sedangkan besarnya pengaruh penggunaan metode eksperimen terhadap minat belajar adalah $\left(\mathrm{t}_{\text {hitung }}=5,774\right)>\left(\mathrm{t}_{\text {tabel }}=1,697\right)$ atau nilai signifikansi $0,00<0,05,(2)$ terdapat pengaruh yang kuat antara variabel penggunaan metode eksperimen terhadap keaktifan belajar sebesar $\mathrm{r}=0,854$ dengan sumbangan sebesar 73\%, sedangkan besarnya pengaruh penggunaan metode eksperimen terhadap keaktifan belajar adalah $\left(\mathrm{t}_{\text {hitung }}=9,437\right)>\left(\mathrm{t}_{\text {tabel }}=\right.$ 
1,697) atau nilai signifikansi $0,00<0,05$, (3) terdapat pengaruh yang kuat antara variabel penggunaan metode eksperimen terhadap hasil belajar sebesar $r=0,531$ dengan sumbangan sebesar $28,2 \%$, sedangkan besarnya pengaruh penggunaan metode eksperimen terhadap hasil belajar adalah $\left(\mathrm{t}_{\text {hitung }}=9,437\right)>\left(\mathrm{t}_{\text {tabel }}=\right.$ 1,697) atau nilai signifikansi $0,00<0,05$, (4) terdapat peningkatan hasil belajar pada materi gelombang bunyi siswa kelas XII IPA 1 SMA Negeri 1 Raja Ampat Kabupaten Raja Ampat sebesar 0,58 yang termasuk dalam kategori sedang.

Kata Kunci : Metode Eksperimen, Minat Belajar, Keaktifan Belajar, Hasil Belajar, Gelombang Bunyi.

\section{PENDAHULUAN}

Tujuan pendidikan menurut UndangUndang Nomor 20 Tahun 2003 adalah mencerdaskan kehidupan bangsa dan mengembangkan manusia Indonesia seutuhnya, yaitu manusia yang beriman dan bertakwa terhadap Tuhan Yang Maha Esa dan berbudi pekerti luhur, memiliki pengetahuan dan keterampilan, kesehatan jasmani dan rohani, kepribadian yang mantap, mandiri serta rasa tanggung jawab kemasyarakatan dan kebangsaan". Pendidikan harus mampu mempersiapkan warga negara agar dapat berperan aktif dalam seluruh lapangan kehidupan, cerdas, aktif, kreatif, terampil, jujur, berdisiplin dan bermoral tinggi, demokratis, dan toleran dengan mengutamakan persatuan bangsa dan bukannya perpecahan.

Secara umum hasil pendidikan yang telah dicapai melalui institusi pendidikan formal belum dapat memuaskan semua pihak terutama para pemerhati pendidikan (stakeholder). Hal ini disinyalir karena masih banyak ketimpangan yang terjadi khususnya sistem pendidikan di tanah air. Disamping itu pondasi pendidikan secara nasional masih lemah. Pelajaran yang diajarkan dalam kurikulum kita belum banyak mengandung basic learning skills, metode pembelajaran yang digunakan masih bersifat konvensional dan tidak menyentuh ranah dimensi siswa itu sendiri, yaitu bagaimana sebenarnya belajar. Hal ini tampak dari rerata hasil belajar siswa yang senantiasa masih sangat memprihatinkan. Dari sisi lain ternyata hasil pendidikan kita juga masih sangat rendah dari segi mentalitas. Hal ini didasari oleh pidato Mantan Presiden Republik Indonesia Megawati Soekarno Putri yang mengatakan bahwa mentalitas bangsa Indonesia tertinggal dibanding negara-negara lain, termasuk dengan negara tetangga terdekat sekalipun.

Berdasarkan hasil pengamatan dan observasi peneliti terhadap tingkat pemahaman mata pelajaran fisika secara 
umum dan khususnya pada materi gelombang bunyi siswa kelas XII IPA SMA Negeri 1 Raja Ampat menunjukkan hasil yang kurang memuaskan (di bawah nilai KKM 70). Ini dapat dilihat dari ulangan harian kelas XII SMA Negeri 1 Raja Ampat yaitu nilai > 70 adalah $15 \%$ dan nilai $<60$ adalah $85 \%$. Selain hasil belajar siswa di bawah nilai KKM, ketidak-minatan dan ketidak-aktifan siswa di dalam kelas XII IPA SMA Negeri 1 Raja Ampat sekitar 90\%, sehingga hasil belajar siswa pun rendah.

Hakikat ilmu fisika merupakan ilmu yang diperoleh dan dikembangkan berdasarkan metode ilmiah dalam penyelesaian suatu masalah dan juga mencari jawaban atas pertanyaan apa, mengapa dan bagaimana gejala-gejala alam terjadi. Fisika merupakan pelajaran yang cukup rumit, yang membutuhkan pemahaman dan pemikiran yang rasional. Jika guru mengajar hanya menggunakan metode ceramah tanpa melibatkan siswa dalam kegiatan pembelajaran, maka siswa cenderung pasif dan tidak memiliki minat untuk belajar, akibatnya siswa lebih banyak menunggu sajian yang diberikan guru. Kondisi ini terkadang menjadikan siswa enggan untuk belajar, kemudian merasakan kejenuhan dan keinginan agar proses belajar cepat selesai, sehingga hasil belajar siswa dalam mempelajari fisika masih sangat rendah.. Ketidakberhasilan siswa dalam menguasai Ilmu fisika kemungkinan disebabkan karena pengetahuan yang dibentuk siswa hanya berasal dari pengetahuan guru yang dipindahkan ke siswa. Siswa hanya menerima informasi dari guru tanpa keterlibatan siswa untuk memecahkan masalah dan mencari jawaban atas pertanyaan apa, mengapa dan bagaimana gejala-gejala alam terjadi. Akhirnya siswa belum bisa menghubungkan antara pengetahuan yang mereka pelajari dan proses pengaplikasian pengetahuan tersebut dalam kehidupan sehari-hari siswa. Sehingga hal ini menjadi masalah yang serius bagi sekolah, karena hal ini dapat menimbulkan rendahnya minat, keaktifan dan hasil belajar siswa kelas XII IPA SMA Negeri 1 Raja Ampat Kabupaten Raja Ampat.

Keberhasilan dalam proses pembelajaran fisika menjadi tanggung jawab bersama antara guru dan siswa. Maka, tugas guru adalah bagaimana menyelenggarakan pembelajaran yang efektif. Untuk itu peneliti mengajukan metode pembelajaran eksperimen. Metode pembelajaran ini merupakan metode pembelajaran yang menekankan praktek langsung cara melakukan/membuat sesuatu, dimana keaktifan siswa sangat dominan dalam pelaksanaannya. Dalam proses belajar 
mengajar dengan metode eksperimen, siswa diberikan kesempatan untuk mengalami sendiri atau melakukan sendiri, mengikuti proses, mengamati suatu objek, menganalisis, membuktikan dan menarik kesimpulan sendiri tentang objek, keadaan atau proses sesuatu.

Berdasarkan penelitian tesis yang dilakukan Joedanarni dan Atik (2011) yang berjudul "Penerapan metode eksperimen dan bermain peran untuk meningkatkan kualitas proses dan prestasi belajar fisika siswa kelas VII-H SMPN 4 Kediri”, diperoleh hasil bahwa penerapan metode ini dapat meningkatkan keaktifan dan hasil belajar.

Rumusan masalah dalam penelitian ini adalah (1) Apakah ada pengaruh metode eksperimen terhadap minat belajar pada materi gelombang bunyi siswa kelas XII IPA SMA Negeri 1 Raja Ampat Kabupaten Raja Ampat? (2) Apakah ada pengaruh metode eksperimen terhadap keaktifan pada materi gelombang bunyi siswa kelas XII IPA 1 SMA Negeri 1 Raja Ampat Kabupaten Raja Ampat?.(3) Apakah ada pengaruh metode ekperimen terhadap hasil belajar pada materi gelombang bunyi siswa kelas XII IPA 1 SMA Negeri 1 Raja Ampat Kabupaten Raja Ampat? (4) Apakah ada peningkatan hasil belajar pada materi gelombang bunyi siswa kelas XII IPA 1 SMA Negeri 1 Raja Ampat Kabupaten Raja Ampat?

\section{METODE PENELITIAN}

Penelitian dilaksanakan di SMA Negeri 1 Raja Ampat Tahun Pelajaran 2016/2017 yang beralamat di kecamatan Waisai Kota Kabupaten Raja Ampat Provinsi Papua Barat. Adapun waktu pelaksanaan penelitian ini mulai dari pembuatan proposal hingga pembuatan laporan penelitian dimulai bulan Agustus 2016 sampai dengan bulan Januari 2017.

Desain penelitian yang digunakan dalam penelitian ini adalah desain "one group pre-test \& post-test", yaitu desain penelitian eksperimen yang dilakukan pada satu kelas

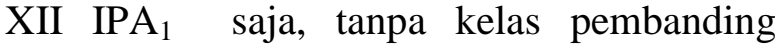
dengan cara memberikan tes awal dan akhir terhadap sampel penelitian. Pada desain ini, dilakukan melalui tiga langkah yaitu: Pertama, mengukur variabel terikat sebelum perlakuan diberikan (pre-test); kedua, memberikan perlakuan eksperimen kepada sampel penelitian; ketiga mengukur kembali variabel terikat setelah perlakuan diberikan (post-test). Penggunaan desain one group pretest \& post-test untuk mengetahui besarnya perbedaan rata-rata skor sebelum dan sesudah diberi perlakuan. 
Dalam hal ini terdapat satu kelompok sampel penelitian yang diberi tes awal untuk mengetahui kondisi awal sebelum perlakuan $\left(\mathrm{O}_{1}\right)$, kemudian pada sampel penelitian diadakan tes akhir untuk mengetahui ada tidaknya akibat yang ditimbulkan dari perlakuan yang diberikan $\left(\mathrm{O}_{2}\right)$. Dengan demikian hasil perlakuan dapat diketahui lebih akurat, karena dapat membandingkan dengan keadaan sebelum diberi perlakuan (Sugiyono, 2016). Desain ini dapat digambarkan seperti berikut:

Tabel 1. One group pre-test \& post-test (Sugiono: 2016)

\begin{tabular}{|c|c|c|}
\hline Pretest & Perlakuan & Posttest \\
\hline $\mathrm{O}_{1}$ & $\mathrm{X}$ & $\mathrm{O}_{2}$ \\
\hline
\end{tabular}

Keterangan :

$$
\begin{array}{rlr}
\mathrm{O}_{1}= & \begin{array}{l}
\text { Nilai pre-test (sebelum diberi } \\
\text { perlakuan). }
\end{array} \\
\mathrm{X} \quad \begin{array}{l}
\text { Treatmen } \\
\text { diberikan/Pembelajaran } \\
\text { menggunakan } \\
\text { eksperimen. }
\end{array} & \begin{array}{l}
\text { yangan } \\
\text { dengan } \\
\text { metode }
\end{array} \\
\mathrm{O}_{2}=\begin{array}{l}
\text { Nilai post-test } \\
\text { perlakuan). }
\end{array} & \text { (setelah diberi }
\end{array}
$$

\footnotetext{
Teknik pengambilan sampel menggunakan teknik purposive sampling. Sampel yang digunakan dalam penelitian ini
}

adalah kelas XII IPA 1 SMA Negeri 1 Raja Ampat sebanyak 35 siswa.

Teknik pengumpulan data yang akan digunakan dalam penelitian ini berupa angket dan tes (pre-test dan post-test). Angket digunakan untuk mengetahui pendapat dari responden tentang minat dan keaktifan belajar siswa, sedangkan tes (pre-test dan post-test) digunakan untuk mengetahui peningkatan hasil belajar dengan menggunakan metode eksperimen. Instrumen yang digunakan dalam penelitian ini adalah angket, dan tes hasil belajar siswa dalam bentuk pilihan ganda.

Uji Normalitas data menggunakan uji Kolmogorov-Smirnov Z yang terdapat pada software SPSS 16.0. Uji Analisis Korelasi, Analisis Linearitas, Analisis Persamaan Regresi, dan pengujian n-Gain dilakukan dengan menggunakan software SPSS 16.0.

\section{PEMBAHASAN}

Data yang diperoleh dengan menggunakan SPSS 16.0 dapat dilihat pada Tabel. 2. sebagai berikut: 
Tabel 2. Analisis Uji Normalitas Data

One-Sample Kolmogorov-Smirnov Test

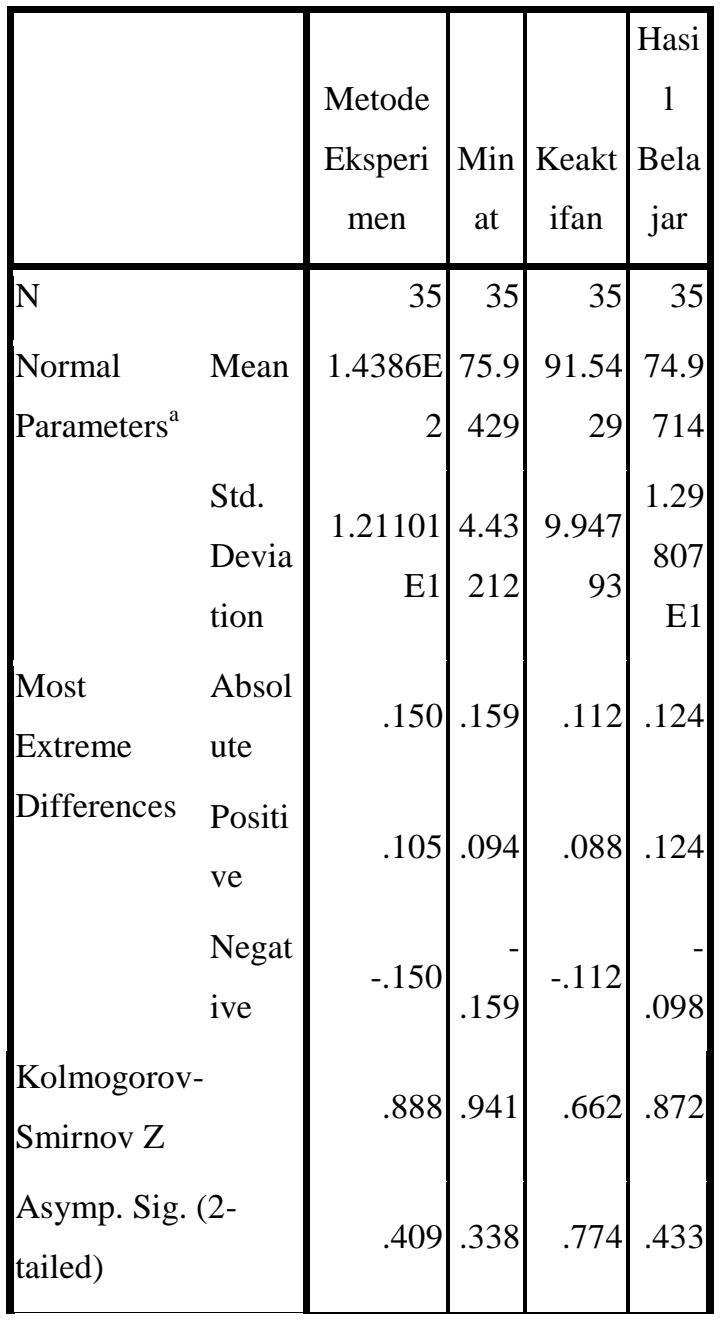

a. Test distribution

is Normal.

Tabel 2 menjelaskan bahwa data tersebut secara keseluruhan berdistribusi normal sehingga analisis korelasi dan regresi dapat dilanjutkan.

Untuk mencari korelasi sederhana antara Penggunaan Metode Eksperimen (X) dan Minat belajar $\left(\mathrm{Y}_{1}\right)$ dilakukan pengujian korelasi sederhana dengan menggunakan aplikasi SPSS 16.0. Hasil dari pengujian tersebut dapat dilihat pada Tabel 3. sebagai berikut:

Tabel 3. Analisis Korelasi Sederhana Antara Penggunaan Metode Eksperimen (X) dengan Minat belajar $\left(\mathrm{Y}_{1}\right)$

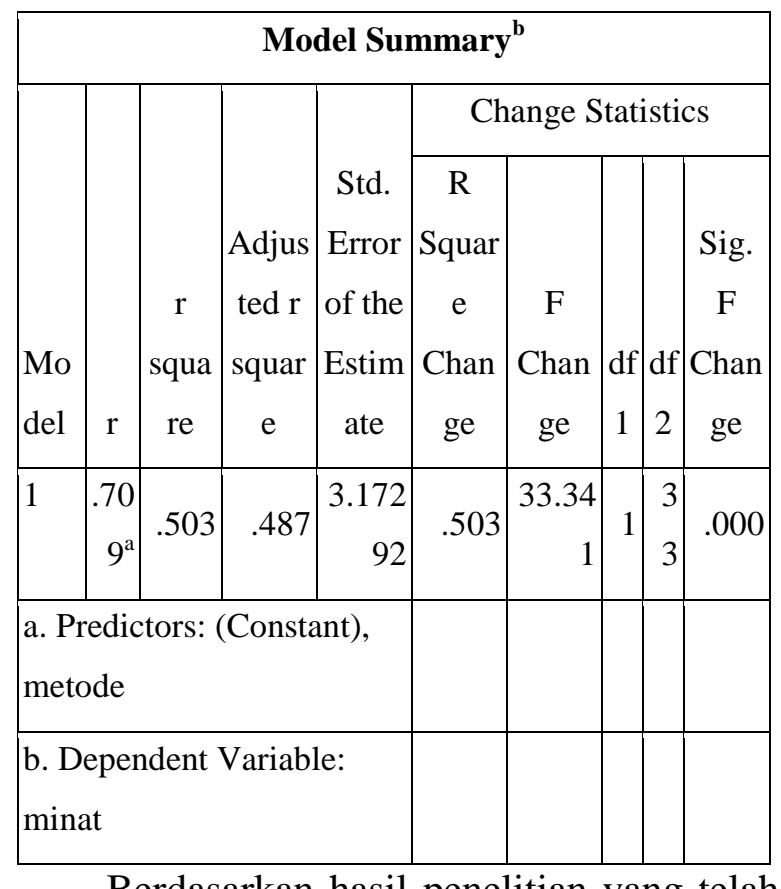

Berdasarkan hasil penelitian yang telah dilakukan pada Tabel 3 diperlihatkan besarnya korelasi antara Penggunaan Metode Eksperimen (X) dengan Minat Belajar Siswa $\left(\mathrm{Y}_{1}\right)$ adalah $\mathrm{r}=0,709$. Hal ini berarti hubungan antara penggunaan metode eksperimen dan minat belajar siswa dikategorikan kuat,dan dijelaskan juga besarnya prosentase sumbangan penggunaan metode eksperimen terhadap minat belajar siswa adalah $\mathrm{r}$ square $=50,3 \%$, sedangkan sisanya dipengaruhi oleh faktor yang lain.

Hasil analisis persamaan regresi penggunaan metode eksperimen $(\mathrm{X})$ terhadap 
minat belajar siswa $\left(\mathrm{Y}_{1}\right)$ pada materi gelombang bunyi kelas XII IPA 1 SMA Negeri 1 Raja Ampat adalah $\mathrm{Y}=$ $38,618+0,259 X$. Konstanta sebesar 38,618 menyatakan bahwa jika tidak ada nilai metode eksperimen maka nilai minat belajar siswa sebesar 38,618. Koefisien regresi $\mathrm{X}$ sebesar 0,259 menyatakan bahwa setiap penambahan 1 nilai metode eksperimen maka nilai minat belajar siswa bertambah sebesar 0,438. Hal ini dapat dilihat pada Tabel 4 berikut ini:

Tabel 4. Analisis Persamaan Regresi Penggunaan Metode Eksperimen (X) terhadap Minat belajar $\left(\mathrm{Y}_{1}\right)$

\begin{tabular}{|c|c|c|c|c|c|c|}
\hline \multicolumn{7}{|c|}{ Coefficients ${ }^{\mathrm{a}}$} \\
\hline \multirow{2}{*}{\multicolumn{2}{|c|}{ Model }} & \multicolumn{2}{|c|}{$\begin{array}{l}\text { Unstandardize } \\
\text { d Coefficients }\end{array}$} & $\begin{array}{c}\text { Standard } \\
\text { ized } \\
\text { Coefficie } \\
\text { nts }\end{array}$ & \multirow[t]{2}{*}{ 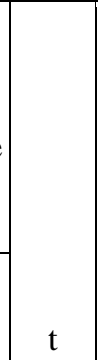 } & \multirow[b]{2}{*}{ Sig. } \\
\hline & & B & $\begin{array}{l}\text { Std. } \\
\text { Error }\end{array}$ & Beta & & \\
\hline 1 & (Constant) & $\begin{array}{r}38.6 \\
18\end{array}$ & 6.486 & & $\begin{array}{r}5.95 \\
4\end{array}$ & $\begin{array}{r}.00 \\
0\end{array}$ \\
\hline & $\begin{array}{l}\text { Metode } \\
\text { Eksperimen }\end{array}$ & .259 & .045 & .709 & $\begin{array}{r}5.77 \\
4\end{array}$ & $\begin{array}{r}.00 \\
0\end{array}$ \\
\hline & $\begin{array}{l}\text { Dependent V } \\
\text { ajar }\end{array}$ & iable: 1 & Iinat & & & \\
\hline
\end{tabular}

Pada Tabel 4 dapat diketahui juga bahwa nilai $\quad\left(\mathrm{t}_{\text {hitung }}=5,774\right)>\left(\mathrm{t}_{\text {tabel }}=1,697\right)$ atau nilai signifikansi $0,000<0$, maka Ho ditolak dan Ha diterima, yang berarti ada pengaruh yang signifikan penggunaan metode eksperimen terhadap minat belajar pada materi gelombang bunyi siswa kelas XII IPA SMA Negeri 1 Raja Ampat Kabupaten Raja Ampat. Hal ini selaras dengan penelitian terdahulu Ningsi Renda Milla (2015), penelitiannya dengan judul "Minat, Nilai Karakter, dan Peningkatan Hasil Belajar Siswa Kelas X SMA Negeri 1 Wewewa Timur Melalui Metode Eksperimen Terbimbing Dalam Pokok Bahasan Pengukuran Besaran dan Satuan. Hasil penelitiannya menunjukkan bahwa minat belajar meningkat sebesar $82,35 \%$ setelah diterapkannya metode eksperimen. Ini berarti ada pengaruh positif yang signifikan metode eksperimen terhadap minat belajar siswa. Hasil ini senada dengan penelitian yang dilakukan oleh peneliti di kelas XII IPA SMA Negeri Raja Ampat Kabupaten Raja Ampat, walaupun peningkatannya hanya sebesar 50,3\%. Faktor yang mungkin melatarbelakangi adanya perbedaan hasil penelitian tersebut, diantaranya adalah: fasilitas dan keadaan sekolah, alat dan fasilitas laboratorium, antusias dan kesiapan siswa, serta waktu dan teknik pelaksanaan penelitian.

Namun walaupun hasilnya tidak sebesar yang diperoleh oleh peneliti sebelumnya, 
minat belajar pada materi gelombang bunyi siswa kelas XII IPA 1 SMA Negeri 1 Raja Ampat tetap mengalami kenaikan. Hal ini bisa terjadi karena menurut Djamarah (2008), seseorang memiliki minat terhadap subjek tertentu cenderung untuk memberikan perhatian yang lebih besar terhadap subjek tertentu. Keadaan ini juga terjadi pada siswa siswa kelas XII IPA 1 SMA Negeri 1 Raja Ampat, yang memiliki perhatian yang lebih besar pada materi gelombang bunyi ketika dalam kegiatan belajar mengajar (KBM) digunakan metode eksperimen. Karena saat KBM berlangsung dengan metode eksperimen, siswa langsung melakukan suatu percobaan tentang gelombang bunyi, mengamati prosesnya, menuliskan hasil percobaan kemudian hasil pengamatannya disampaikan ke kelas (Roestiyah NK : 2008). Sehingga dengan demikian dengan adanya metode eksperimen tersebut, minat belajar pada materi gelombang bunyi siswa kelas XII $\mathrm{IPA}_{1}$ SMA Negeri 1 Raja Ampat meningkat (Tabel 5) :

Tabel 5.Analisis Korelasi Sederhana Penggunaan Metode Eksperimen (X) dengan Keaktifan belajar $\left(\mathrm{Y}_{2}\right)$

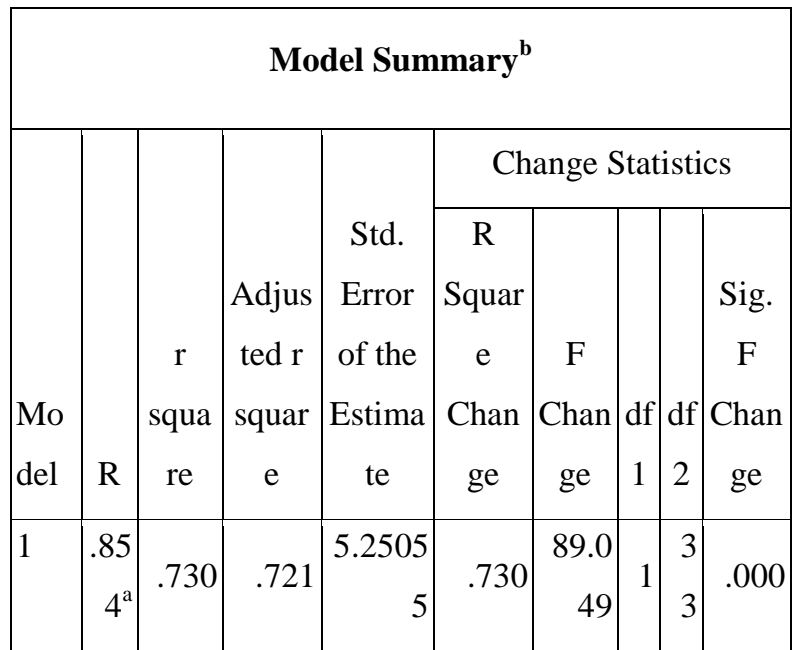

a. Predictors: (Constant), metode

b. Dependent Variable: keaktifan

Pada Tabel 5 ditunjukkan bahwa besarnya korelasi antara Penggunaan Metode Eksperimen (X) dengan Keaktifan Belajar Siswa $\left(\mathrm{Y}_{2}\right)$ adalah $\mathrm{r}=0,854$. Hal ini berarti hubungan antara penggunaan metode eksperimen dan keaktifan belajar siswa dikategorikan kuat,dan dijelaskan juga besarnya presentase sumbangan penggunaan metode eksperimen terhadap keaktifan belajar siswa adalah $\mathrm{r}$ square $=73,0 \%$, sedangkan sisanya dipengaruhi oleh faktor yang lain.

Hasil analisis persamaan regresi penggunaan metode eksperimen $(\mathrm{X})$ terhadap keaktifan belajar siswa $\left(\mathrm{Y}_{2}\right)$ pada materi gelombang bunyi kelas XII IPA 1 SMA Negeri 1 Raja Ampat adalah $\quad \mathrm{Y}=$ $9,397+0,702 X$. Konstanta sebesar 9,397 menyatakan bahwa jika tidak ada nilai metode eksperimen maka nilai keaktifan 
belajar siswa sebesar $-9,397$. Koefisien regresi $\mathrm{X}$ sebesar 0,702 menyatakan bahwa setiap penambahan 1 nilai metode eksperimen maka nilai keaktifan belajar siswa bertambah sebesar 0,702 . Tanda negatif pada intersep dalam hal ini tidak selalu harus diinterpretasikan. Menurut Gujarati (2006) nilai intersep tidak selalu berarti karena seringkali jangkauan nilai variabel bebas tidak memasukkan nol sebagai salah satu nilai yang diamati. Hal ini ditunjukkan pada Tabel 6 berikut ini:

Tabel.6.Analisis Persamaan Regresi Penggunaan Metode Eksperimen (X) terhadap Keaktifan belajar $\left(\mathrm{Y}_{2}\right)$

\begin{tabular}{|c|c|c|c|c|c|c|}
\hline \multicolumn{7}{|c|}{ Coefficients $^{a}$} \\
\hline \multirow{2}{*}{\multicolumn{2}{|c|}{ Model }} & \multicolumn{2}{|c|}{$\begin{array}{l}\text { Unstandardize } \\
\text { d Coefficients }\end{array}$} & $\begin{array}{l}\text { Standardi } \\
\text { zed } \\
\text { Coefficie } \\
\text { nts }\end{array}$ & \multirow[b]{2}{*}{$\mathrm{t}$} & \multirow[b]{2}{*}{ Sig. } \\
\hline & & $\mathrm{B}$ & $\begin{array}{l}\text { Std. } \\
\text { Error }\end{array}$ & Beta & & \\
\hline & (Constant) & -9.397 & 10.733 & & $\begin{array}{r}- \\
.875\end{array}$ & .388 \\
\hline & $\begin{array}{l}\text { Metode } \\
\text { Eksperime } \\
\text { n }\end{array}$ & .702 & .074 & .854 & $\begin{array}{r}9.43 \\
7\end{array}$ & .000 \\
\hline \multicolumn{6}{|c|}{ a. Dependent Variable: keaktifan } & \\
\hline
\end{tabular}

Berdasarkan hasil analisis pada Tabel 6 diperoleh

nilai $\left(\mathrm{t}_{\text {hitung }}=9.437\right)>\left(\mathrm{t}_{\text {tabel }}=1,697\right)$ atau nilai signifikansi $0,000<0,05$, maka Ho ditolak dan Ha diterima, yang berarti ada pengaruh yang signifikan penggunaan metode eksperimen terhadap keaktifan belajar pada materi gelombang bunyi siswa kelas XII IPA 1 SMA Negeri 1 Raja Ampat. Hal ini selaras dengan penelitian terdahulu; Joedanarni \& Atik (2011), penelitiannya yang judul "Penerapan metode eksperimen dan bermain peran untuk meningkatkan kualitas proses dan prestasi belajar fisika siswa kelas VII-H SMP Negeri 4 Kediri”. Hasil penelitian menunjukkan adanya peningkatan pelaksanaan pembelajaran yakni keaktifan siswa meningkat mencapai $75,00 \%-90,00 \%$ - Hal ini senada dengan penelitian yang dilakukan oleh peneliti. Hasil yang diperoleh oleh peneliti keaktifan siswa meningkat mencapai $73 \%$, terlihat bahwa perbedaannya tidak terlalu jauh dengan hasil penelitian sebelumnya.

Hasil pengujian hipotesa (Ha) telah membuktikan bahwa adanya pengaruh yang signifikan penggunaan metode eksperimen terhadap keaktifan belajar siswa dengan besar $\mathrm{t}_{\text {hitung }}=9,437$ atau nilai signifikansi 0,000. Besar prosentase peningkatan keaktifan belajar siswa yang diberikan oleh metode eksperimen adalah 73,0\%. Adanya peningkatan keaktifan siswa pada materi gelombang bunyi kelas XII IPA ${ }_{1}$ SMA Negeri 
1 Raja Ampat ini memperlihatkan bahwa dengan metode eksperimen siswa lebih aktif dalam proses kegiatan belajar mengajar, karena metode eksperimen merupakan suatu metode mengajar dimana siswa dilibatkan langsung untuk mengamati peristiwa atau kejadian yang terjadi pada suatu obyek di bawah bimbingan guru.dan merupakan metode yang cocok digunakan pada mata pelajaran sains, karena pada metode ini siswa diberi kesempatan untuk menyusun konsepkonsep dalam struktur kognitifnya yang kemudian dapat diimplementasikan dalam kesehariannya. Adanya keterlibatan langsung siswa dalam kegiatan belajar mengajar inilah yang memungkinkan siswa untuk lebih berperan aktif dalam kegiatan pembelajaran.

Hasil observasi peneliti sebelumnya pada siswa SMA Negeri 1 Raja Ampat, khususnya pada siswa kelas XII IPA keaktifan belajar siswa cukup rendah, hal ini karena sebelum digunakan metode eksperimen siswa tidak terlibat secara langsung dalam kegiatan belajar mengajar. Siswa hanya duduk diam dan mendengarkan penjelasan dari guru. Hanya beberapa kali menjawab pertanyaan yang diajukan oleh guru, dan itu pun hanya beberapa siswa saja. Namun setelah adanya penggunaan metode eksperimen ini siswa dituntut untuk lebih banyak terlibat langsung dalam kegiatan pembelajaran mulai dari perencanaan: yaitu meliputi kegiatan menetapkan alat-alat yang diperlukan, menentukan langkah-langkah apa saja yang perlu dicatat dan variabel-variabel yang harus dikontrol, sampai dengan pelaksanaan yang meliputi: mengumpulkan laporan dan memproses kegiatan. Sehingga dengan demikian semua siswa akan terlibat lebih aktif selama kegiatan proses belajar mengajar. Hal ini sesuai dengan hasil analisis dari penelitian ini yang membuktikan bahwa dengan penggunaan metode eksperimen, keaktifan belajar siswa lebih meningkat.

Tabel.7.Analisis Korelasi Sederhana Penggunaan Metode Eksperimen (X) dengan Hasil Belajar Siswa $\left(\mathrm{Y}_{3}\right)$

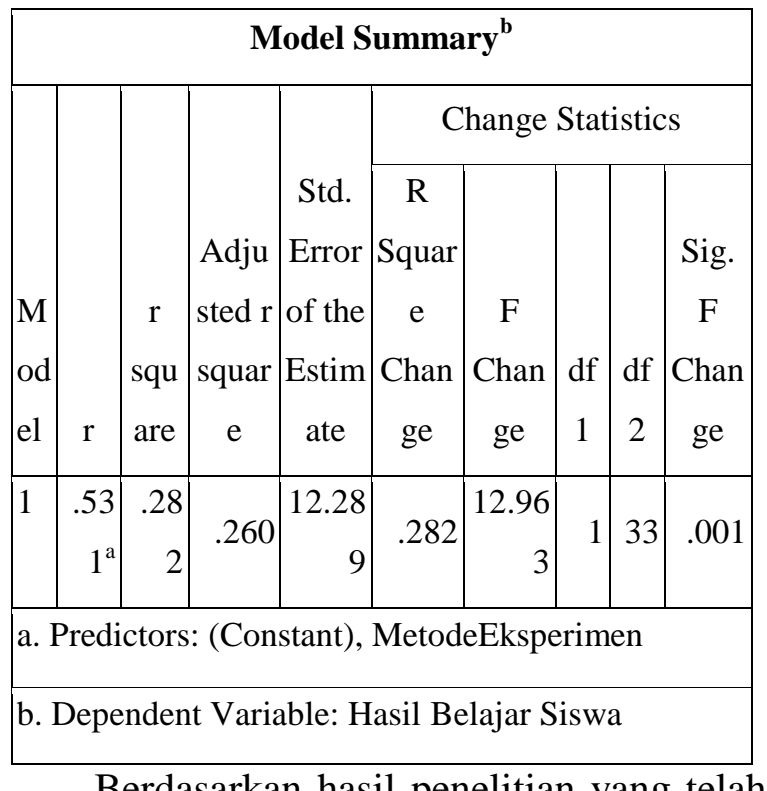

Berdasarkan hasil penelitian yang telah dilakukan pada Tabel 6 ditunjukkan besarnya korelasi antara Penggunaan Metode Eksperimen (X) dengan Hasil Belajar Siswa 
$\left(\mathrm{Y}_{3}\right)$ adalah $\mathrm{r}=0,531$. Hal ini berarti hubungan antara penggunaan metode eksperimen dan hasil belajar siswa dikategorikan cukup kuat, dan dijelaskan juga besarnya prosentase sumbangan penggunaan metode eksperimen terhadap hasil belajar siswa adalah

rsquare $=$ $28,2 \%$, sedangkan $71,8 \%$ dipengaruhi oleh faktor yang lain.

Hasil analisis persamaan regresi penggunaan metode eksperimen $(\mathrm{X})$ terhadap hasil belajar siswa $\left(\mathrm{Y}_{3}\right)$ pada materi gelombang bunyi kelas XII IPA1 SMA Negeri 1 Raja Ampat adalah $\mathrm{Y}=-6.082+$ 0,627X (halaman 159). Konstanta sebesar 14.146 menyatakan bahwa jika tidak ada nilai metode eksperimen maka nilai hasil belajar siswa sebesar -6.082. Koefisien regresi $X$ sebesar 0,627 menyatakan bahwa setiap penambahan 1 nilai metode eksperimen maka nilai keaktifan belajar siswa bertambah sebesar 0,627. Hal ini dapat dilihat pada Tabel 7 sebagai berikut:

Tabel.7.Analisis Persamaan Regresi Penggunaan Metode Eksperimen (X) terhadap Hasil Belajar Siswa $\left(\mathrm{Y}_{3}\right)$

\begin{tabular}{|c|c|c|c|c|c|}
\hline \multicolumn{6}{|c|}{ Coefficients $^{\mathrm{a}}$} \\
\hline \multirow[b]{2}{*}{ Model } & \multicolumn{2}{|c|}{$\begin{array}{l}\text { Unstandardize } \\
\text { d Coefficients }\end{array}$} & $\begin{array}{c}\text { Standardi } \\
\text { zed } \\
\text { Coefficie } \\
\text { nts }\end{array}$ & & \\
\hline & B & $\begin{array}{l}\text { Std. } \\
\text { Error }\end{array}$ & Beta & $\mathrm{t}$ & Sig. \\
\hline 1 (Constant) & 6.082 & 21.654 & & -.281 & .781 \\
\hline $\begin{array}{l}\text { MetodeEksper } \\
\text { imen }\end{array}$ & .627 & .174 & .531 & $\begin{array}{r}3.60 \\
0\end{array}$ & .001 \\
\hline a. Dependent Vari & lable: $\mathrm{H}$ & Iasil & & & \\
\hline
\end{tabular}

Pada Tabel 7 diperlihatkan bahwa nilai $\left(t_{\text {hitung }}=3.346\right)>\left(t_{\text {tabel }}=1,697\right)$ atau nilai signifikansi $0,000<0,05$, maka Ho ditolak dan Ha diterima, yang berarti ada pengaruh yang signifikan penggunaan metode eksperimen terhadap hasil belajar pada materi gelombang bunyi siswa kelas XII IPA SMA Negeri 1 Raja Ampat. Hal ini selaras dengan penelitian terdahulu; Mastin D. Poiyo (2013), penelitiannya dengan judul "Pengaruh Penerapan Metode Eksperimen terhadap Hasil Belajar Siswa pada Materi Listrik Dinamis", hasil penelitian menunjukkan bahwa terdapat pengaruh yang signifikan hasil belajar sebelum diterapkan metode eksperimen dan setelah diterapkan metode eksperimen sebesar $t_{\text {hitung }}=4,73$. Hal ini senada dengan hasil yang diperoleh oleh peneliti yakni sebesar $t_{\text {hitung }}=3,600$. 
Perbedaan hasil penelitian yang dilakukan oleh peneliti dengan Mastin D. Poiyo (2013) tidak terlalu jauh. Namun jika dibandingkan dengan penelitian Joedanarni \& Atik (2011) hasil prestasi belajar yang dicapai ketuntasan belajar siswa sebesar $55,00 \%-86,00 \%$, sedangkan hasil penelitian peneliti hanya sebesar 28,2\%. Hal ini bisa saja terjadi adanya perbedaan kepintaran dan pemahaman siswa, selain itu bisa juga faktor kesiapan mental siswa. Walaupun demikian, hasil pengujian hipotesa (Ha) pada penelitian ini telah membuktikan bahwa adanya pengaruh yang signifikan penggunaan metode eksperimen terhadap hasil belajar siswa dengan besar $t_{\text {hitung }}=3,600$ dan nilai signifikansi 0,001. Walaupun besar presentase peningkatan hasil belajar siswa yang diberikan oleh metode eksperimen hanya sebesar 28,2\%, namun tetap memberikan pengaruh yang positif terhadap peningkatan hasil belajar siswa.

Adanya peningkatan hasil belajar siswa pada materi gelombang bunyi kelas XII IPA SMA Negeri 1 Raja Ampat ini memperlihatkan bahwa dengan metode eksperimen siswa dapat lebih memahami materi gelombang bunyi yang disampaikan oleh guru. Menurut Sudjana, (2004 : 22), hasil belajar merupakan bagian terpenting dalam pembelajaran. Hasil belajar adalah kemampuan-kemampuan yang dimiliki siswa setelah menerima pengalaman belajarnya. Kemampuan-kemampuan tersebut mencakup aspek kognitif, afektif, dan psikomotorik. Aspek-aspek tersebut dapat diperoleh siswa saat proses pembelajaran berlangsung dengan melalui penggunaan metode eksperimen. Karena di dalam metode eksperimen bukan hanya mengandalkan kemampuan siswa dari sisi kognitifnya saja, namun juga dari sisi afektif dan psikomotorik.

Tabel 8. Rata - rata $n$ - Gain Tes Awal dan Tes Akhir RPP

\begin{tabular}{|l|c|c|c|c|c|l|}
\hline $\mathbf{N}$ & Res- & $\mathbf{n - ~}$ & $\begin{array}{c}\text { n- } \\
\text { Gain }\end{array}$ & $\begin{array}{c}\text { n- } \\
\text { Gain } \\
\text { Pon den }\end{array}$ & $\begin{array}{c}\text { Rata } \\
\mathbf{2}\end{array}$ & $\mathbf{K E T}$ \\
$\mathbf{R P P}$ & $\begin{array}{c}\text { RPP } \\
\mathbf{2}-\end{array}$ & \\
\hline 1 & Res-1 & 1,00 & 1,00 & 1,00 & 1,00 & Tinggi \\
\hline 2 & Res-2 & 0,50 & 0,50 & 0,57 & 0,52 & Sedang \\
\hline 3 & Res-3 & 0,40 & 0,50 & 0,33 & 0,41 & Sedang \\
\hline 4 & Res-4 & 0,40 & 0,20 & 0,88 & 0,49 & Sedang \\
\hline 5 & Res-5 & 0,57 & 0,88 & 0,80 & 0,75 & Tinggi \\
\hline 6 & Res-6 & 0,44 & 0,33 & 0,33 & 0,37 & Sedang \\
\hline 7 & Res-7 & 0,20 & 0,44 & 0,00 & 0,21 & Rendah \\
\hline 8 & Res-8 & 0,38 & 0,50 & 0,40 & 0,43 & Sedang \\
\hline 9 & Res-9 & 0,38 & 0,56 & 0,56 & 0,50 & Sedang \\
\hline 10 & Res-10 & 0,44 & 0,50 & 0,40 & 0,45 & Sedang \\
\hline 11 & Res-11 & 0,50 & 0,63 & 0,86 & 0,66 & Sedang \\
\hline 12 & Res-12 & 0,57 & 0,63 & 0,50 & 0,57 & Sedang \\
\hline 13 & Res-13 & 0,25 & 0,67 & 1,00 & 0,64 & Sedang \\
\hline 14 & Res-14 & 0,50 & 0,57 & 0,67 & 0,58 & Sedang \\
\hline 15 & Res-15 & 0,20 & 0,33 & 0,38 & 0,30 & Sedang \\
\hline 16 & Res-16 & 0,56 & 0,50 & 1,00 & 0,69 & Sedang \\
\hline 17 & Res-17 & 0,60 & 0,63 & 0,40 & 0,54 & Sedang \\
\hline 18 & Res-18 & 0,75 & 1,00 & 1,00 & 0,92 & Tinggi \\
\hline
\end{tabular}




\begin{tabular}{|l|l|l|l|l|l|l|}
\hline 19 & Res-19 & 0,20 & 0,57 & 0,57 & 0,45 & Sedang \\
\hline 20 & Res-20 & 0,00 & 0,33 & 0,50 & 0,28 & Rendah \\
\hline 21 & Res-21 & 0,17 & 0,50 & 0,60 & 0,42 & Sedang \\
\hline 22 & Res-22 & 0,75 & 0,75 & 1,00 & 0,83 & Tinggi \\
\hline 23 & Res-23 & 1,00 & 1,00 & 1,00 & 1,00 & Tinggi \\
\hline 24 & Res-24 & 1,00 & 1,00 & 1,00 & 1,00 & Tinggi \\
\hline 25 & Res-25 & 0,56 & 0,40 & 0,89 & 0,62 & Sedang \\
\hline 26 & Res-26 & 0,75 & 0,86 & 1,00 & 0,87 & Tinggi \\
\hline 27 & Res-27 & 0,29 & 0,86 & 0,83 & 0,66 & Sedang \\
\hline 28 & Res-28 & 0,33 & 0,56 & 0,50 & 0,46 & Sedang \\
\hline 29 & Res-29 & 0,78 & 0,57 & 0,17 & 0,51 & Sedang \\
\hline 30 & Res-30 & 0,38 & 0,38 & 0,50 & 0,42 & Sedang \\
\hline 31 & Res-31 & 0,71 & 0,57 & 0,63 & 0,64 & Sedang \\
\hline 32 & Res-32 & 0,88 & 0,63 & 0,67 & 0,73 & Tinggi \\
\hline 33 & Res-33 & 0,57 & 0,50 & 0,00 & 0,36 & Sedang \\
\hline 34 & Res-34 & 0,14 & 0,50 & 0,43 & 0,36 & Sedang \\
\hline 35 & Res-35 & 0,63 & 0,43 & 0,50 & 0,52 & Sedang \\
\hline Rata-rata & $\mathbf{0 , 5 1}$ & $\mathbf{0 , 5 9}$ & $\mathbf{0 , 6 2}$ & $\mathbf{0 , 5 8}$ & Sedang \\
\hline
\end{tabular}

Berdasarkan hasil analisis skor tes awal dan tes akhir pada Tabel 8 ditunjukkan bahwa pelaksanaan RPP 1, RPP 2, dan RPP 3 dengan menggunakan metode eksperimen terdapat peningkatan yang cukup signifikan. Rata-rata $n$-Gain RPP 1 sebesar 0,51, RPP 2 sebesar 0,59, RPP 3 sebesar 0,62, dan n-Gain rata-sata RPP 1 sampai dengan RPP 3 sebesar 0,58, maka termasuk kategori sedang.

\section{SIMPULAN}

Hasil penelitian ini dapat disimpulkan sebagai berikut: (1) Terdapat pengaruh yang signifikan penggunaan metode eksperimen terhadap minat belajar pada materi gelombang bunyi siswa kelas XII IPA ${ }_{1}$ SMA Negeri 1 Raja Ampat Kabupaten Raja Ampat sebesar $r=0,709$ dengan besar sumbangan adalah 50,3\%, hal ini juga sesuai dengan kriteria pengujian hipotesis bahwa $\left(t_{\text {hitung }}=\right.$ $5,774)>\left(t_{\text {tabel }}=1,697\right)$ atau nilai signifikansi $0,000<0,05$, (2) Terdapat pengaruh yang signifikan penggunaan metode eksperimen terhadap keaktifan belajar pada materi gelombang bunyi siswa kelas XII IPA ${ }_{1}$ SMA Negeri 1 Raja Ampat Kabupaten Raja Ampat sebesar $r=0,854$ dengan sumbangan sebesar $73 \%$ dan hasil pengujian hipotesis $\quad\left(t_{\text {hitung }}=\right.$ $9,437)>\left(\mathrm{t}_{\text {tabel }}=1,697\right)$ atau nilai signifikansi $0,000<0,05$. (3) Terdapat pengaruh yang signifikan penggunaan metode eksperimen terhadap keaktifan belajar pada materi gelombang bunyi siswa kelas XII IPA 1 SMA Negeri 1 Raja Ampat Kabupaten Raja Ampat sebesar $r=0,854$ dengan sumbangan sebesar $73 \%$ dan hasil pengujian hipotesis $\left(\mathrm{t}_{\text {hitung }}=9,437\right)>\left(\mathrm{t}_{\text {tabel }}=1,697\right)$ atau nilai signifikansi $0,000<0,05$. (4) Hasil belajar gelombang bunyi siswa Kelas XII IPA 1 SMA Negeri 1 Raja Ampat Kabupaten Raja Ampat yang meliputi mengerjakan soal tes awal dan tes akhir mengalami peningkatan sebesar 0,58 yang termasuk dalam kategori sedang. 
SARAN

Berdasarkan simpulan yang telah dilakukan, maka saran yang dapat diberikan dalam penelitian ini yaitu: (1)kepada guru, baik SD, SMP/MTs, SMA/SMK/MA dalam pembelajaran agar menggunakan metode eksperimen dalam usaha meningkatkan minta, keaktifan, dan hasil belajar siswa, khususnya pelajaran fisika dan pelajaran lain pada umumnya. (2) Bagi penelitian selanjutnya, dalam pembuatan instrumen tes hendaknya setiap indikator disiapkan lebih banyak butir soal agar setelah divalidasi dan reliabilatasnya semua indikator mewakili. Seain itu juga saat proses penelitian berlangsung hendaknya memperhatikan kesiapan alat dan mental siswa. (3) Peneliti lebih memperhatikan waktu dan teknik pelaksanaan penelitian.dan dianjurkan sebisa mungkin mempersiapkan alat-alat yang akan digunakan oleh siswa.

\section{DAFTAR PUSTAKA}

Gujarati, Damodar. 2006. Dasar-Dasar Ekonometrika. Jakarta: Erlangga.

Joedanarni, Atik. 2011. "Penerapan Metode Eksperimen dan Bermain Peran untuk Meningkatkan Keaktifan dan Prestasi Belajar Fisika pada Siswa Kelas VII-H SMPN 4 Kediri". Tesis. Jurusan Program Studi Pendidikan Dasar
Konsentrasi Pendidikan IPA

SMP, Program Pascasarjana Universitas Negeri Malang.

Ningsi Renda Milla, 2015. Minat, Nilai Karakter, dan Peningkatan Hasil Belajar Siswa Kelas X SMA Negeri 1 Wewewa Timur Melalui Metode Eksperimen Terbimbing Dalam Pokok Bahasan Pengukuran Besaran dan Satuan.Yogyakarta : Universitas Sanata Dharma Yogyakarta.

Poiyo Mastin D. 2013. Pengaruh Penerapan Metode Eksperimen terhadap Hasil Belajar Siswa pada Materi Listrik Dinamis. Gorontalo: Universitas Negeri Gorontalo.

Riduwan, 2010. Teknik Menyusun Tesis. Bandung: Alfabeta.

Risalatul L. Shoum. 2014. Metode Eksperimen Dengan Teknik 'Master' Pada Pembelajaran Fisika Di SMP. Jurnal Pembelajaran Fisika. Jember: Universitas Negeri Jember.

Rosetiyah NK. 2008. Strategi Belajar Mengajar. Jakarta: Rineka Cipta.

Sugiyono. 2016. Statistika untuk Penelitian. Bandung : Alfabeta.

Sudjana. 2004. Dasar-dasar Proses Belajar Mengajar. Bandung: Sinar Baru.

Syaiful Bahri Djamarah. 2008. Psikologi Belajar. Jakarta: PT.Rineka Cipta.

Trinandita. 2008. Prestasi Belajar. Tersedia di http://ipotes.wordpress.com/presta si-belajar 25 Juli 2016) (diakses tanggal 
Yuliani Hadma dkk. 2012. Pembelajaran Fisika Dengan Pendekatan Keterampilan Proses Dengan Metode Eksperimen Dan Demonstrasi Ditinjau Dari Sikap
Ilmiah Dan Kemampuan Analisis. Universitas Sebelas Maret. Surakarta: Jurnal Inkuiri. ISSN: 2252-7893, Vol 1, No 32012 (hal 207-216). 